\title{
Conservation status of Astyanax biotae (Characiformes: Characidae) in Mato Grosso do Sul, upper Paraná River basin, Brazil
}

\author{
Maria José Alencar Vilela ${ }^{1 *}$ \\ Francisco Severo-Neto ${ }^{2}$ \\ Fernando Rogério Carvalho ${ }^{2}$ \\ ${ }^{1}$ Laboratório de Ictiologia, Universidade Federal de Mato Grosso do Sul, Campus de Três Lagoas \\ Avenida Ranulpho Marques Leal, 3484, CEP 88040-960, Três Lagoas - MS, Brazil \\ ${ }^{2}$ Instituto de Biociências, Laboratório de Ictiologia, Universidade Federal de Mato Grosso do Sul \\ Campo Grande - MS, Brazil \\ * Autor para correspondência \\ mjavilela@yahoo.com.br
}

Submetido em 19/04/2018

Aceito para publicação em 24/10/2018

\section{Resumo}

Estado de conservação de Astyanax biotae (Characiformes: Characidae) em Mato Grosso do Sul, bacia do alto Paraná, Brasil. Astyanax biotae é uma espécie originalmente descrita de um afluente do rio Paranapanema, bacia do alto rio Paraná. Durante amostragens realizadas em drenagens dos rios Ivinhema e Verde, no sistema do alto Paraná, em Mato Grosso do Sul, exemplares de A. biotae foram coletados em cabeceiras de pequenos riachos e em lagoas de várzea, tanto em Unidades de Conservação como em áreas de agricultura intensiva. Os dados morfomerísticos de 20 indivíduos analisados foram similares aos da série-tipo. Exemplares-testemunhos estão depositados nas coleções ictiológicas da UFMS (ZUFMS), UEMS (CPUEMS) e UNESP (DZSJRP). Com base nos critérios da IUCN, sugerimos a classificação como Menos Preocupante (LC) no estado de Mato Grosso do Sul, considerando principalmente a inexistência de ameaças efetivas em duas das áreas de ocorrência da espécie, situadas dentro de Unidades de Conservação. No entanto, reforçamos a urgência em medidas para a proteção das regiões de cabeceiras de riachos, a fim de evitar o aumento do desmatamento, assoreamento e poluição agrícola, problemas recorrentes no Cerrado, que comprometem severamente a manutenção desses hábitats e suas espécies. É necessário investir em estudos sobre a biologia da espécie e ampliar as amostragens, buscando diminuir os vazios amostrais ainda existentes nas drenagens estaduais.

Palavras-chave: Áreas úmidas; Cabeceiras de riachos; Espécie nativa; Ictiofauna; Unidade de Conservação

\section{Abstract}

Astyanax biotae was described from an affluent of the Paranapanema River, in the upper Paraná River basin. During sampling carried out for research projects in the drainage of the Ivinhema and Verde rivers, in the upper Paraná River system, A. biotae individuals were collected in headwaters of small streams and várzea lagoons, both in protected and intensive agriculture areas. The morphometric and meristic data of 20 
individuals analyzed were similar to those of the standard series. Vouchers are deposited in the ichthyological collections of UFMS (ZUFMS), UEMS (CPUEMS) and UNESP (DZSJRP). Based on IUCN criteria, we suggest this species be classified as Least Concern (LC) in Mato Grosso do Sul State, considering the absence of effective threats in two of the occurrence areas, which are located within protected areas. However, we emphasize the establishment of measures to protect headwater regions in order to avoid an increase in deforestation, siltation and agricultural pollution, which are recurrent problems in the Cerrado that severely compromise the maintenance of these habitats and their species. It is necessary to invest in studies about natural history of the species and to increase sampling, seeking to reduce the sample gaps that still exist in the Mato Grosso do Sul drainages.

Key words: Headwaters; Ichthyofauna; Native species; Protected area; Wetlands

\section{Introduction}

The aquatic systems of Mato Grosso do Sul State are distributed among the drainages of the upper Paraguay River basin, including the complex Pantanal biome, and the upper Paraná River basin, which occupies the centraleastern and southern regions of the state. These regions contain about 360 valid fish species (FROEHLICH et al., 2017). This diversity is an underestimation, as shown by recent new species descriptions and records (e.g., Melanorivulus nigropunctatus Volcan, Klotzel \& Lanés, 2017 and M. ofaie Volcan, Klotzel \& Lanés, 2017, Laetacara araguaiae Ottoni \& Costa, 2009 and Brachyhypopomus walteri Sullivan, Zuanon \& Cox Fernandes, 2013).

Characidae is the richest family of order Characiformes, with about 1,200 valid species described (ESCHMEYER; FONG, 2018) and more than 70 species in the region of the upper Paraná River basin (LANGEANI et al., 2007). Astyanax Baird \& Girard, 1854 represents one of the most species-rich genera among the Characidae and has a wide distribution in the Neotropics. It is also one of the most taxonomically complex genera, resulting in varying estimates of species numbers (GÉRY, 1977; GARUTTI, 1999; GARUTTI; BRITSKI, 2000; LIMA et al., 2003). Although Astyanax systematics are still unclear and not fully understood (MENEZES et al., 2007; BERTACO, 2014; LUCENA; SOARES, 2016), the taxon currently has about 150 valid species (ESCHMEYER; FONG, 2018), many of which have been recently discovered (OLIVEIRA, 2017).

Astyanax biotae Castro \& Vari, 2004(Characiformes: Characidae) was described based on specimens collected in Água Mole Stream, a small drainage belonging to Diamante do Norte County, Paraná State, in the
Paranapanema River basin, upper Paraná River system (CASTRO; VARI, 2004). This species differs from other upper Paraná River congeners by its reticulated pattern of the body, resulting from the dark pigmentation on the margins of the scales and by the distal margin of the base of the dorsal fin vertically passing through the first or second branched rays of the anal fin.

The species is mentioned in the fish checklist of Mato Grosso do Sul State (FROEHLICH et al., 2017), but with no mention of a voucher specimen. Recently, Oliveira et al. (2018) confirmed the species in Mato Grosso do Sul. In this article we provide detailed data about the occurrence of Astyanax biotae into Mato Grosso do Sul State, including new records for the eastern part of state, and assess its regional conservation status.

\section{Materials and Methods}

\section{Study area}

In Mato Grosso do Sul, the upper Paraná River basin was originally almost entirely covered by the Cerrado biome and is characterized by an Aw climate (tropical savanna with a dry winter) according to the Köppen-Geiger classification. There is also a small area with a humid temperate climate in the southern region of the state, with a dry winter and hot summer (Cwa) (RIBEIRO; WALTER, 1998), occupied by the Atlantic Forest biome. According to Ecological-Economic Zoning (ZEE-MS, 2009), only a few fragments of seasonal semideciduous forest and semideciduous alluvial forest remain in this region, whose landscape has been modified by large monocultures. The specimens 
of Astyanax biotae reported in this paper come from different research projects and were captured in four localities (Figure 1 and Table 1), described below:

a) Égua Stream, municipality of Angélica, a first-order stream, tributary of the Piravevê River, tributary of the Ivinhema River. The site is in the region of headwaters and still has fragments of riparian forest depleted by the advance of pastures, on the edges of a dirt road.

b) Headwaters of Rapadura Stream, a first-order stream tributary of Ribeirão Pombo, affluent of the Verde River. The collections were made during expeditions for a biological inventory aimed at developing the Management Plan of Parque Natural Municipal do Pombo (PNMP), Três Lagoas municipality, according to law $n^{-} 9.985$ of 15/07/2000 (ICMBIO, 2009). The stream is on the northern boundary of the conservation unit and is about $3.8 \mathrm{~km}$ long. It presents calm and limpid waters, a sandy substrate with deposits of plant litter and organic matter in the margins, as well as many macrophytes and aquatic grasses, and is surrounded by typical vereda vegetation (palm swamp) represented by Mauritia flexuosa Mart., or the buriti palm (Figure 2a).

c) Marsh in the headwaters of São Bento Stream, a small tributary of the Vacaria River, affluent of the Ivinhema River (Figure 2b). The collection site is located along Highway BR-060, in the municipality of Dois Irmãos do Buriti, on the Serra de Maracaju, exactly in the watershed transition between the basins of the upper Paraná and upper Paraguay

FIGURE 1: Astyanax biotae records in the upper Paraná River basin, Mato Grosso do Sul, Brazil. The dashed line represents the border between the upper Paraná River and upper Paraguay River basins. In blue, the Ivinhema River basin, and in green, the Verde River basin. The star represents the type locality of $A$. biotae; numbers represents the new records presented in this work: 1 . Égua Stream; 2. Rapadura Stream; 3. São Bento Stream; 4. Lagoon at PEVRI.

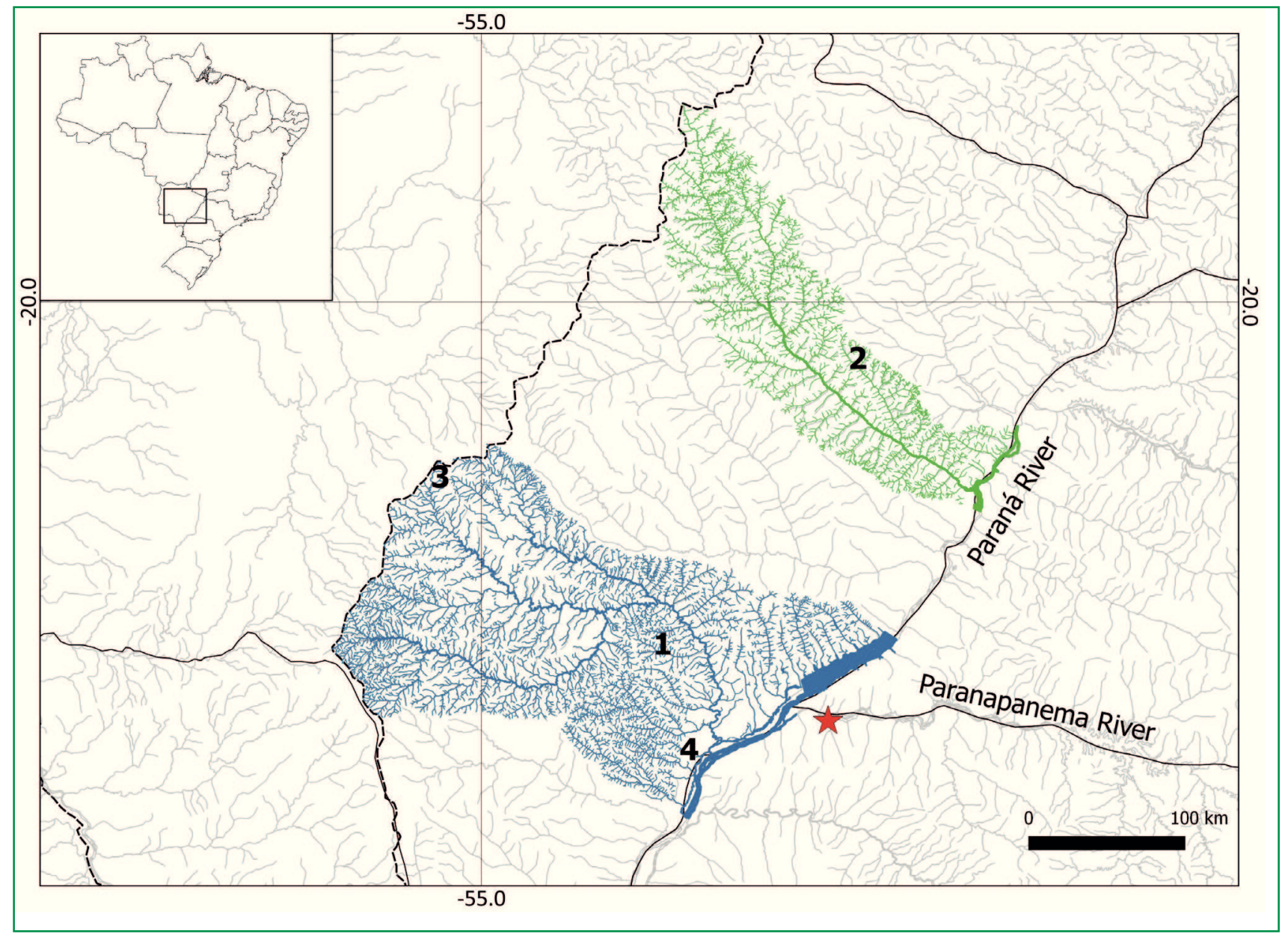


TABLE 1: Records of Astyanax biotae collections in Mato Grosso do Sul State, upper Paraná River basin. In Number of individuals column, the numbers represent the total number of individuals in the lot and those analyzed herein, respectively.

\begin{tabular}{lcccccc}
\hline \multicolumn{1}{c}{ Local } & Date & Lat S & Long W & $\begin{array}{c}\text { Altitude } \\
(\mathbf{m})\end{array}$ & $\begin{array}{c}\text { Number of } \\
\text { individuals }\end{array}$ & Voucher \\
\hline Égua Stream & 22.04 .2005 & $22^{\circ} 10^{\prime} 30^{\prime \prime}$ & $53^{\circ} 50^{\prime} 10^{\prime \prime}$ & 335 & $17 / 11$ & DZSJRP 7510 \\
Rapadura Stream & 01.03 .2012 & $20^{\circ} 20^{\prime} 06^{\prime \prime}$ & $52^{\circ} 35^{\prime} 30^{\prime \prime}$ & 399 & $18 / 6$ & ZUFMS 5541 \\
São Bento Stream & 30.08 .2016 & $21^{\circ} 02^{\prime} 01^{\prime \prime}$ & $55^{\circ} 18^{\prime} 16^{\prime \prime}$ & 563 & $13 / 1$ & ZUFMS 04898 \\
Lagoon at PEVRI & 28.05 .2017 & $22^{\circ} 51^{\prime} 48^{\prime \prime}$ & $53^{\circ} 38^{\prime} 32.8^{\prime \prime}$ & 240 & $2 / 2$ & CPUEMS 0537 \\
\hline
\end{tabular}

river basins. During the rainy season this area becomes a large floodplain of about 60 ha.

d) Lagoon in Parque Estadual das Várzeas do Rio Ivinhema (PEVRI), a conservation unit located in the Ivinhema River basin. The collection site is located in an area of várzea, regional nomenclature given to lowland waters occupied by pioneer vegetation under fluvial/lacustrine influence (e.g., Panicum prionitis Nees, Sagittaria montevidensis Cham. \& Schtdl., Cyperus sp., Pfaffia iresionoides Sprengel, and Eichhornia spp.) (IMASUL, 2008).

\section{Data sampling and laboratory processing}

The specimens were collected with a dragging net and sieve, both with $2.5 \mathrm{~mm}$ mesh. Collected specimens (License SISBIO 15044-1) were fixed in $10 \%$ formaldehyde and later transferred to $70 \%$ alcohol. Sampling occurred in shallow places, between $10 \mathrm{~cm}$ and $150 \mathrm{~cm}$ deep, and the specimens were identified based on the original description (CASTRO; VARI, 2004).

Morphometric and meristic measurements were performed on 20 specimens according to Fink and Weitzman (1974), using a digital caliper with precision of $0.1 \mathrm{~mm}$, for comparisons with the descriptive data of the species. All proportions were estimated in relation to the standard length (SL), with the exception of eye diameter, interorbital width, snout length and maxillary length, referred to as head length (HL).

Voucher specimens were deposited in the following ichthyological collections: Coleção Zoológica da Universidade Federal de Mato Grosso do Sul (ZUFMS),
Coleção de Peixes da Universidade Estadual de Mato Grosso do Sul (CPUEMS), and Coleção de Peixes do Departamento de Zoologia e Botânica, Universidade Estadual de São Paulo "Júlio de Mesquita Filho" São José do Rio Preto, SP (DZSJRP).

FIGURE 2: Partial view of the collection sites of Astyanax biotae. a. Rapadura Stream, in the Parque Natural Municipal do Pombo; b. Marsh on the headwaters of São Bento Stream during the dry season.
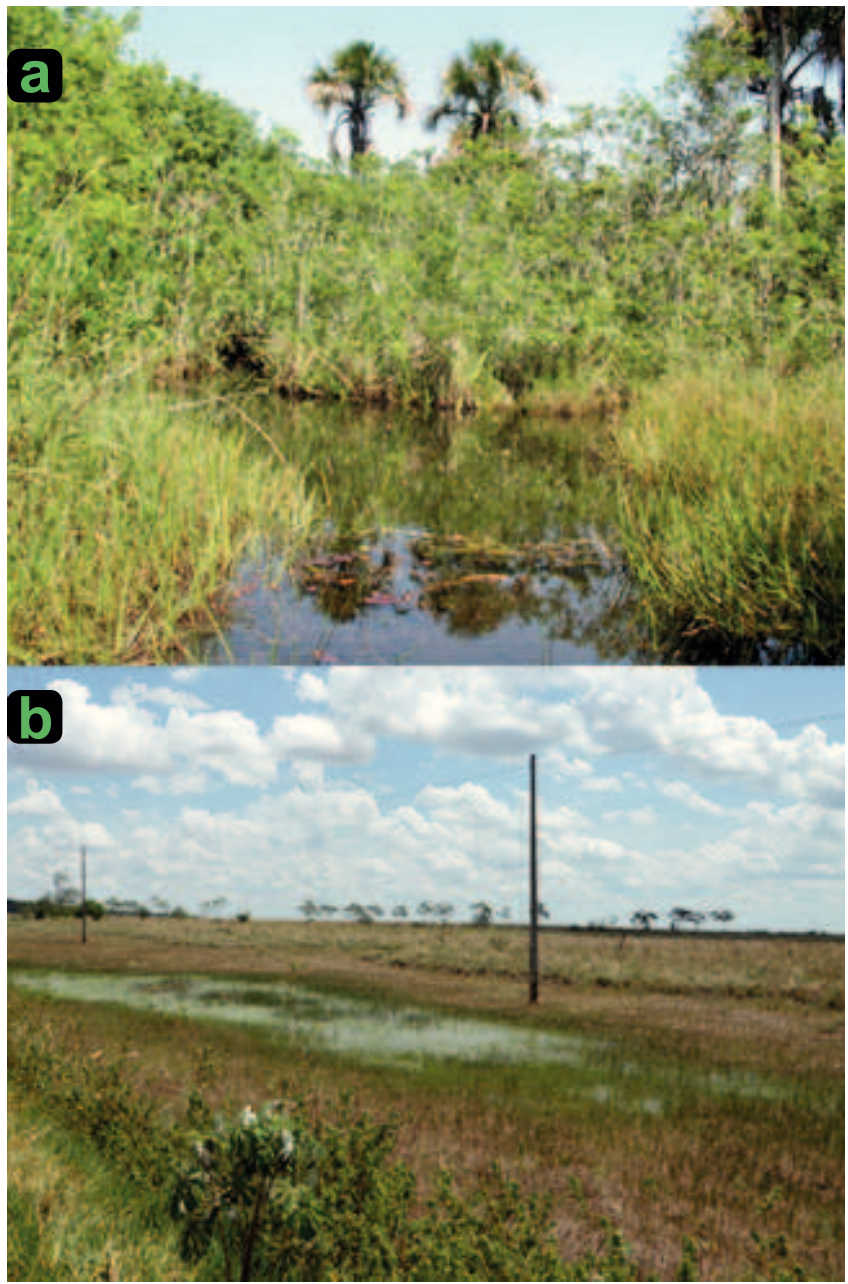


\section{Analysis}

Based on the International Union for Conservation of Nature (IUCN) guidelines, adopted by the Chico Mendes Institute for Biodiversity Conservation for the Brazilian Red List assessment of fish species (ICMBIO, 2013; IUCN, 2013; 2017), we listed the conservation category of this species.

\section{Results}

Astyanax biotae is distinguished from congeners by the presence of a vertically elongated humeral spot and a slightly dark strip in the medial portion of the flanks, more visible from the dorsal fin to the caudal peduncle, where it forms a dark rounded spot. We observed that newly captured specimens show the following: upper medial portion of the body and head with a slight yellowish-brown color, mixed with silver-bluish tones on the flanks, overlapping the dark lateral stripe; anterior portion of the abdomen silverish; hyaline pectoral and pelvic fins, slightly yellowish; dorsal and anal fins with slight grayish-blue coloration and a dark marginal band; and gray-blue caudal fin, more pronounced in the upper and lower lobes, with dark median rays (Figure 3). In fixed individuals, these nuances of color disappear, with the yellowish-brown tone prevailing in the body and the slightly bluish hyaline of the fins, as shown in Figure 3. The specimens from PEVRI showed a more pronounced reticulated pattern and the spot in the caudal peduncle was also more marked in relation to the other samples, which may be related to small differences in habitat conditions (e.g., water color, chemical parameters, availability of light in the water column, etc.) or to phenotypical variations.

FIGURE 3: Astyanax biotae, ZUFMS-4898, $39.40 \mathrm{~mm}$ SL, from São Bento Stream, Mato Grosso do Sul State, Brazil: exemplar sample in vivo (top) and in $70 \%$ alcohol (bottom).

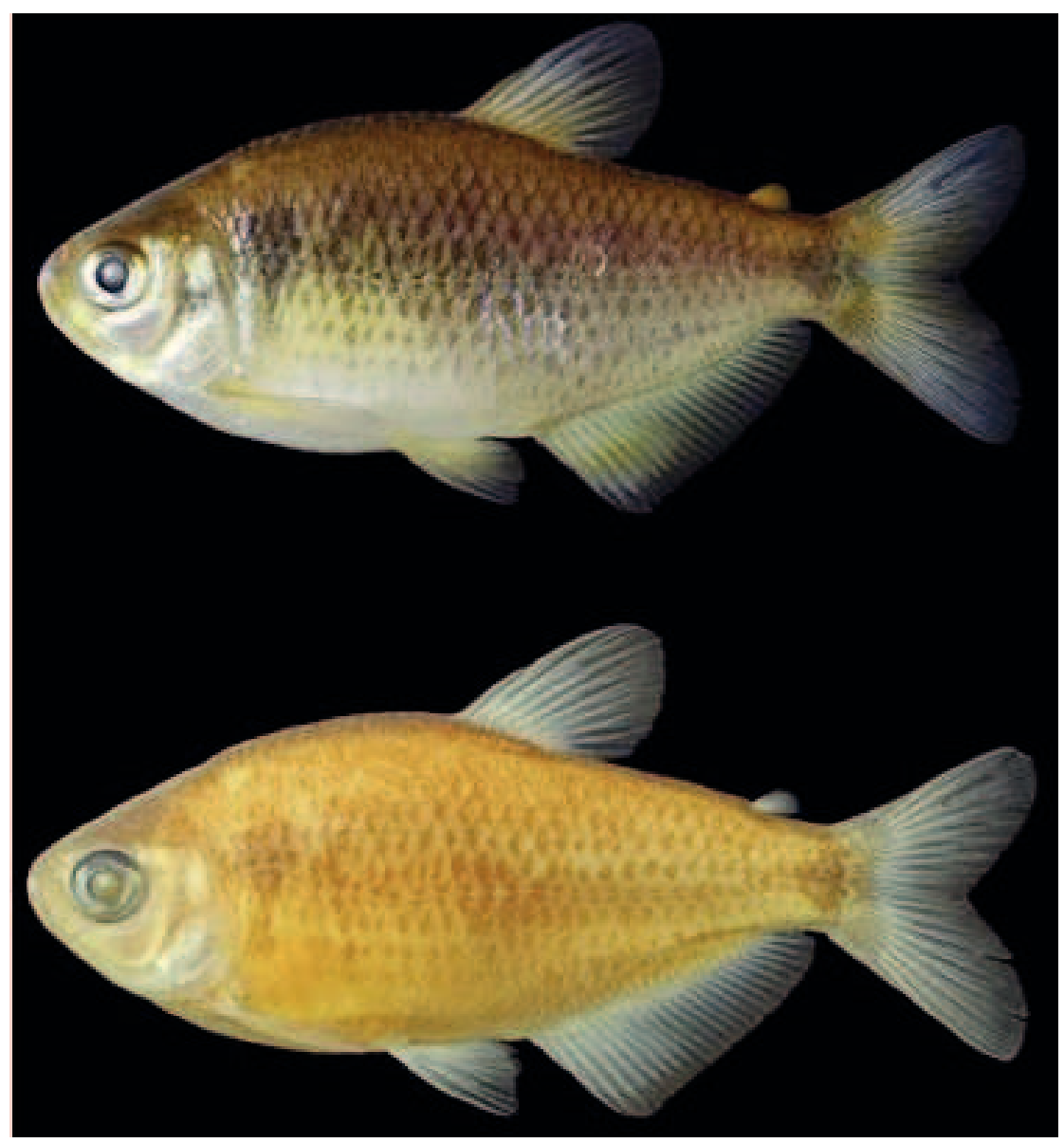


Morphometric and meristic data of the measured individuals are presented in Table 2. The specimens present premaxillary teeth in two rows, four or five teeth on the inner premaxillary row and complete lateral line, conferring with the basic characteristics defined for Astyanax Baird \& Girard, 1854.
Standard length varied between $17.5 \mathrm{~mm}$ and 39.4 $\mathrm{mm}$, with an average of $30.31 \mathrm{~mm}$, less than the average recorded $(44.2 \mathrm{~mm})$ for the paratypes. As observed by Castro and Vari (2004) in individuals from streams of the Paranapanema River basin, we also noticed a slight increase in body height in larger individuals, although

TABLE 2: Morphometric and meristic data of Astyanax biotae recorded in the upper Paraná River basin. $\mathrm{N}=$ number of examined specimens, $\mathrm{SD}=$ Standard Deviation.

\begin{tabular}{|c|c|c|c|c|}
\hline Morphometric data & $\mathbf{N}$ & Range (\%) & Mean (\%) & SD \\
\hline & \multicolumn{4}{|c|}{ Percents of SL } \\
\hline Standard length $(\mathrm{mm})$ & 20 & $17.5-39.4$ & 30.31 & - \\
\hline Body depth & 20 & $33.2-42.3$ & 37.67 & 2.32 \\
\hline Head length & 20 & $26.8-32.9$ & 29.68 & 1.57 \\
\hline Head depth & 20 & $26.3-33.7$ & 29.65 & 2.12 \\
\hline Predorsal distance & 20 & $53.2-58.5$ & 56.11 & 1.33 \\
\hline Prepelvic distance & 20 & $45.7-53.8$ & 48.45 & 1.93 \\
\hline Pelvic fin to anal fin distance & 20 & $13.7-20.0$ & 16.48 & 1.82 \\
\hline Caudal peduncle depth & 20 & $11.3-13.9$ & 12.62 & 0.74 \\
\hline Dorsal fin base length & 20 & $12.5-16.5$ & 14.74 & 0.93 \\
\hline Anal fin base length & 20 & $28.9-36.3$ & 32.95 & 1.84 \\
\hline Pectoral fin length & 20 & $19.9-23.7$ & 22.43 & 1.55 \\
\hline Pelvic fin length & 20 & $15.4-21.5$ & 18.10 & 1.42 \\
\hline Dorsal fin length & 19 & $26.4-31.3$ & 29.91 & 1.40 \\
\hline Anal fin length & 20 & $17.8-24.2$ & 20.98 & 1.90 \\
\hline Caudal peduncle length & 20 & $9.7-13.1$ & 11.53 & 0.94 \\
\hline Dorsal fin to adipose fin distance & 20 & $34.8-39.2$ & 37.10 & 1.27 \\
\hline Orbit to dorsal fin origin distance & 20 & $38.2-44.3$ & 40.59 & 1.27 \\
\hline \multirow[t]{2}{*}{ Dorsal fin to caudal peduncle distance } & 20 & $46.7-53.8$ & 49.16 & 1.70 \\
\hline & \multicolumn{4}{|c|}{ Percents of HL } \\
\hline Upper jaw length & 19 & $36.4-44.2$ & 41.25 & 2.09 \\
\hline Orbital diameter & 20 & $31.6-40.0$ & 36.62 & 2.59 \\
\hline Snout length & 20 & $20.7-27.1$ & 24.01 & 2.11 \\
\hline Interorbital width & 20 & 33.4-39.2 & 36.18 & 1.91 \\
\hline Meristic data & $(\mathbf{N})$ & Range & \multicolumn{2}{|c|}{ Mode } \\
\hline Dorsal fin rays & 20 & ii, $8-9$ & \multicolumn{2}{|c|}{ ii,9 } \\
\hline Anal fin rays & 20 & iii,22-25 & \multicolumn{2}{|c|}{ iii,24 } \\
\hline Caudal fin rays & 20 & $\mathrm{i}, 8-10 / 8-10, \mathrm{i}$ & \multicolumn{2}{|c|}{$\mathrm{i}, 9 / 8, \mathrm{i}$} \\
\hline Pectoral fin rays & 20 & $\mathrm{i}, 10-12$ & \multicolumn{2}{|c|}{$\mathrm{i}, 12$} \\
\hline Pelvic fin rays & 20 & $\mathrm{i}, 6-8$ & \multicolumn{2}{|c|}{$\mathrm{i}, 7$} \\
\hline Pored lateral line scales & 19 & $31-35$ & \multicolumn{2}{|c|}{34} \\
\hline
\end{tabular}




\begin{tabular}{lccc}
\hline Meristic data & (N) & Range & Mode \\
\hline Circumpeduncular scales & 20 & $12-15$ & 14 \\
Scale rows above lateral line & 20 & $6-7$ & 6 \\
Scale rows below lateral line & 20 & $4-6$ & 5 \\
Scale sheath along anal-fin base & 19 & $8-16$ & 12 \\
Predorsal scales & 20 & $9-13$ & 11 \\
Maxillary teeth & 19 & $0-1$ & 1 \\
Premaxillary teeth - outer row & 19 & $4-5$ & 4 \\
Premaxillary teeth - inner row & 19 & $4-5$ & 5 \\
Dentary teeth & 19 & $4-5$ & 4 \\
\hline
\end{tabular}

more specimens are necessary to make a more complete analysis about this morphological feature. Body height/ $\mathrm{SL}$ ratio in the smallest individual, $17.2 \mathrm{~mm}$, was $33.16 \%$, while in the largest, $39.4 \mathrm{~mm}$, it was $42.8 \%$.

In general, the morphometric data are similar to those obtained by Castro and Vari (2004), as were the observed meristic data. However, scale sheath along anal-fin base showed one of the largest amplitudes of variation, between 8 and 16, with a mode equal to 12 (vs. 8-11, mode 9), and one specimen had four premaxillary teeth in the inner row (vs. five).

\section{Discussion}

According to Langeani et al. (2007), nine species of Astyanax occur in the upper Paraná River basin. Astyanax altiparanae (=A. lacustris), A. bockmanni, $A$. fasciatus, and $A$. paranae are the most widely distributed, in the basin, while A. schubarti, A. trierythropterus and two new species not yet described show more restricted distributions, like $A$. biotae. For the latter species, records of its occurrence at the time of the study were only from two small streams in the Ivinhema and Paranapanema River basins (CASTRO; VARI, 2004; CETRA et al., 2016; FROELICH et al., 2017), including the recent paper by Oliveira et al. (2018).

The samples recorded in the present study extend the distribution area in Mato Grosso do Sul State, adding records for the upper reaches of the Ivinhema River basin and in the Verde River basin. These heavily anthropized
Cerrado and forest areas include a large part of the headwaters that supply the two large hydrographic basins of the state, which still have considerable gaps in relation to what is known about the ichthyofauna, especially small species, despite some progress made in recent years. The records are recent, with the earliest dated to 2005, and coincide with the advance of inventories and collections in more isolated, previously not sampled, sites. It is even possible that the actual distribution of the species is greater than the one known to date, considering the numerous sample gaps that exist throughout the state. Nevertheless, we believe that $A$. biotae is a species with a more restricted distribution to certain areas, essentially because its presence has not been registered in other areas, even in densely sampled places. In addition, the reduced number of individuals in the catches so far suggest that populations are also small.

The capture sites of the samples are somewhat similar, being lentic or semilentic water types, protected by aquatic macrophytes and linked to nearby lotic drainages. Two occurrences were recorded within protected areas. In PEVRI, occurrences were characterized by ponds with good water quality and other habitat attributes. This area has been protected from anthropic actions since December 1999, when the decree of expropriation was issued for the effective implementation of the unit (IMASUL, 2008). In PNMP, the captures occurred in pools formed by blocked culverts for a stream by an old road and reasonably wellpreserved habitat conditions. The other two occurrences were recorded in stretches of semi-dammed streams 
due to the presence of roads. One is a point of Égua Stream that is cut by an unpaved road and surrounded by pastures and crops. Another is São Bento Stream, that is a floodplain cut by a heavily used highway and completely surrounded by monocultures, mainly sugarcane and soybeans. In spite of wire fencing that separates the wetland from cultivated areas, the site is easily accessible, including by potential fishers, along the highway. These environments are similar to the type locality, Água Mole Stream, which is also located in an area of agricultural activity with a corresponding loss of native forest. These types of habitats are quite common in the landscape of Mato Grosso do Sul, especially from the central to the southern part of the state, but remain neglected in terms of ichthyofaunal surveys, although important information about the biology of species with restricted ranges can be obtained from them (e.g., SEVERO-NETO; VOLCAN, 2018).

It is noteworthy that the Paranapanema River, the basin of the type locality, flows into the Paraná River practically at the same latitudinal line as that of Ivinhema River floodplain, on the right bank. Thus, the distance between the Paranapanema and Ivinhema river systems is relatively small, which may explain the natural occurrence of the species in the two areas. Rapadura Stream, in turn, is located in an isolated and difficult access point in the upper section of the Pombo River, in the Verde River basin. Between the Verde and Ivinhema river basins, there are two other important drainage systems, the Pardo and Taquaruçu rivers, where ichthyofaunal surveys are practically non-existent. It is possible that $A$. biotae occurs at more points among the known ones, but, so far, the large sampling gaps do not allow us to establish a hypothesis that explains the distribution pattern of the species. Its presence in the drainage over the watershed between the Paraná and Paraguay river basins (São Bento Stream) also raises the possibility of its occurrence In the headwaters of upper Paraguay River streams due to the shared ichthyofauna between drainages. This possibility of shared ichthyofauna between basins is reinforced by the recent record in the upper Paraná River basin of Astyanax lineatus (FERREIRA et al., 2017), a species previously only known from the upper Paraguay River basin, which was caught in an area under similar conditions of contact between headwaters and is about $100 \mathrm{~km}$ from São Bento Stream, the westernmost point of the distribution of $A$. biotae.

In streams from the Paranapanema River basin, Cetra et al. (2016) considered A. biotae a rare species, with low occurrence frequency, abundance and biomass. Its conservation status, at the national level, was considered Deficient Data (DD) (ICMBIO, 2016). However, Oliveira et al. (2018) suggest its classification status as Least Concern (LC) at the national level, considering the absence of real threats within the protected area (PEVRI).

According to the methodology and guidelines of the IUCN, we classified $A$. biotae as Least Concern (LC) in Mato Grosso do Sul State. The species occurs in two sites of headwater areas surrounded by crops or pasture and, hence, is susceptible to various types of threats, including loss/alteration of habitat, cattle trampling, siltation, ground leveling, deforestation and contamination by pesticides in areas in contact with monocultures. On the other hand, the registration of the species within two protected areas offers this fish a relative degree of protection. In PEVRI, the total area is large (more than 73,000.00 ha) and there are no significant threat records so far. In PNMP, we also did not detect effective threats; however, we warn that the place of occurrence of $A$. biotae is at the border of the protected area and, to a certain extent, more exposed to the interferences of the surroundings. Thus, it is important to strengthen surveillance in that area, in order to guarantee greater protection to the creek and, consequently, to the species that inhabit it.

This classification reinforces the national classification suggested by Oliveira et al. (2018). To avoid re-evaluation of this status, it is necessary to protect the headwater areas, which are continuously impacted by human activities. No information is available on the size of populations/subpopulations and the number of adult individuals within them, but the data to date suggest that A. biotae is a rare and infrequent species. Thus, there is a need for more studies about the natural history of the species and the subpopulations recorded to date. Further, ichthyofauna sampling in the region should increase in order to reduce the sample gaps that still exist in Mato Grosso do Sul drainages. 


\section{Acknowledgements}

We are grateful to Mr. Klaus Duarte Barreto, Casa da Floresta Environmental Consultancy, who organized the on-site inventory in PNMP and obtained the authorization for data collection. We would like to thank Gabriel Guedes, Gabriel Nakamura, Josileide de Castro Santana, Maria Angélica Galli Dutra, Mariana Oliveira, Marina Souza, Thais Buzetti Barbosa and Túlio Arantes, trainee students from the Ichthyology Laboratory at UFMS/Campus Três Lagoas, for their participation while making collections. We also want to thank Dr. Yzel Suárez Rondon (UEMS-CPUEMS) and Dr. Francisco Langeani (UNESP-DZSJRP) for providing the samples from fish collections.

\section{References}

BERTACO, V. A. Astyanax douradilho, a new characid fish from the rio Tramandaí system, southern Brazil (Characiformes: Characidae). Zootaxa, Auckland, v. 3794, n. 3, p. 492-500, 2014.

CASTRO, R. M. C.; VARI, R. P. Astyanax biotae, a new species of stream fish from the Rio Paranapanema basin, upper Paraná system, southeastern Brazil (Ostariophysi: Characiformes: Characidae). Proceedings of the Biological Society of Washington, Washington, v. 117, n. 3, p. 330-338, 2004.

CETRA, M.; MATTOX, G. M. T.; FERREIRA, F. C.; GUINATO, R. B.; SILVA, F. V.; PEDROSA, M. Headwater stream fish fauna from the Upper Paranapanema River basin. Biota Neotropica, Campinas, v. 16, n. 3, p. 1-6, 2016.

ESCHMEYER, W. N.; FONG, J. D. Catalog of fishes. 2018. Available in: <http://researcharchive.calacademy.org/research/ ichthyology/catalog/SpeciesByFamily.asp $>$. Access in: 5 January 2018.

FERREIRA, F. S.; VICENTIN, W.; SÚAREZ, Y. R. Astyanax lineatus (Perugia, 1891) (Characiformes: Characidae): first record in the upper Paraná River basin, Mato Grosso do Sul, Brazil. Checklist, Rio Claro, v. 13, n. 2, p. 1-4, 2017.

FINK, W. L.; WEITZMAN, S. H. The so-called cheirodontin fishes of Central America with descriptions of two new species (Pisces: Characidae). Smithsonian Contributions to Zoology, Washington, v. 172, p. 1-46, 1974.

FROEHLICH, O.; CAVALLARO, M.; SABINO, J.; SÚAREZ, Y. R.; VILELA, M. J. A. Checklist da ictiofauna do estado de Mato Grosso do Sul, Brasil. Iheringia, Série Zoologia, Porto Alegre, v. 107 (supl.), p. 1-14, 2017.

GARUTTI, V. Descrição de Astyanax argyrimarginatus sp. n. (Characiformes, Characidae) procedente da bacia do rio Araguaia, Brasil. Revista Brasileira de Biologia, São Carlos, v. 59, n. 4, p. 581-591, 1999.

GARUTTI, V.; BRITSKI, H. A. Descrição de uma espécie nova de Astyanax (Teleostei: Characidae) da bacia do alto rio Paraná e considerações sobre as demais espécies do gênero na bacia. Comunicações do Museu de Ciências e Tecnologia da PUC, Série Zoologia, Porto Alegre, v. 13, p. 65-88, 2000.

GÉRY, J. Characoid of the World. New Jersey: T. F. H. Publ., 1977. 672 p.

ICMBIO. Sistema Nacional de Unidades de Conservação. Série Legislação ICMBio, Vol. 1. 2009. Brasília: ICMBio/MMA. Available from: $<$ http://www.icmbio.gov.br/portal/images/stories/ comunicacao/legislacaoambientalvolume1.pdf $>$. Access in: 12 November 2017.

ICMBIO. Aplicação de critérios e categorias da UICN na avaliação da fauna brasileira. Versão 2. 2013. Brasília: ICMBio/ MMA, Available from: <http://www.icmbio.gov.br/cepsul/images/ stories/especies_ameacadas/publicacoes/2013_apostila_aplicacao criterios_categorias_UICN_versao_2.0.pdf $>$. Access in: $1 \overline{2}$ November 2017.

ICMBIO. Avaliação do risco de extinção da fauna brasileira. 2016. Available from: <http://www.icmbio.gov.br/portal/ faunabrasileira/avaliacao-do-risco-de-extincao $>$. Access in: 12 December 2017.

IMASUL. Plano de Manejo do Parque Estadual das Várzeas do Rio Ivinhema. Campo Grande: Instituto de Meio Ambiente do Mato Grosso do Sul, 2008. Available from: $<$ http://www.servicos. ms.gov.br/imasuldownloads/PlanosdeManejo/planomanejoPEVRI. pdf $>$. Access in: 28 November 2017.

LANGEANI, F.; CASTRO, R. M. C.; OYAKAWA, O. T.; SHIBATTA, O. A.; PAVANELLI, C. S.; CASATTI, L. Diversidade da ictiofauna do Alto Rio Paraná: composição atual e perspectivas futuras. Biota Neotropica, Campinas, v. 7, n. 3, p. 1-17, 2007.

LIMA, F. C. T.; MALABARBA, L. R.; BUCKUP, P. A.; SILVA, J. F. P.; VARI, R. P.; HAROLD, A.; BENINE, R.; OYAKAWA, O.; PAVANELLI, C. S.; MENEZES, N.; LUCENA, C.; MALABARBA, C. S. L. M.; LUCENA, Z. M.; REIS, R. E.; LANGEANI, F.; CASSATI, L.; BERTACO, V. A.; MOREIRA, C.; LUCINDA, P. H. F. Genera Incertae sedis in Characidae. In: REIS, R. E.; KULLANDER, S. O.; FERRARIS JR., C. J. (Ed.). Check list of the freshwater fishes of South and Central America. Porto Alegre: EDIPUCRS, 2003. p. 106-169.

LUCENA, C. A. S.; SOARES, H. G. Review of species of the Astyanax bimaculatus "caudal peduncle spot" subgroup sensu Garutti \& Langeani (Characiformes, Characidae) from the Rio La Plata and Rio São Francisco drainages and coastal systems of southern Brazil and Uruguay. Zootaxa, Auckland, v. 4072, n. 1, p. 101-125, 2016.

MENEZES, N. A.; WEITZMAN, S. H.; OYAKAWA, O. T.; LIMA, F. C. T.; CASTRO, R. M. C.; WEITZMAN, M. J. Peixes de água doce da Mata Atlântica: lista preliminar e comentários sobre conservação de peixes de água doce neotropicais. São Paulo: Museu de Zoologia, Universidade de São Paulo, 2007. 407 p.

OLIVEIRA, C. A. M. Revisão taxonômica do complexo de espécies Astyanax scabripinnis sensu Bertaco \& Lucena (2006) (Ostariophysi: Characiformes: Characidae). 2017. 339 f. Tese (Doutorado em Ecologia de Ambientes Aquáticos Continentais) Universidade Estadual de Maringá, Maringá. 2017.

OLIVEIRA, C. A. M.; OliveIRA, A. G.; PAVANELli, C. S. Expanding the geographical distribution of Astyanax biotae Castro 
\& Vari, 2004 (Characiformes, Characidae), with comments on its conservation status. Check List, Rio Claro, v. 14, n. 2, p. 387-392, 2018.

RIBEIRO, J. F.; WALTER, B. M. T. Fitofisionomias do bioma Cerrado. In: SANO, S. M.; ALMEIDA, S. P. (Ed.). Cerrado: ambiente e flora. Planaltina: EMBRAPA - CPAC, 1998. p. 89-166.
SEVERO-NETO, F.; VOLCAN, M. V. Population dynamics of Melanorivulus rossoi, a restricted geographic distribution killifish species. Environmental Biology of Fishes, New York, v. 101, p. $245-255,2018$.

ZEE-MS - ZONEAMENTO ECOLÓGICO-ECONÔMICO DO ESTADO DE MATO GROSSO DO SUL. Anexo I da Lei no 3.839, de 28/12/2009, 2009. Available from: <http://193.43.36.109/docs/ pdf/bra116233AnnexI.pdf $>$. Access in: 14 November 2017. 